\title{
The Implementation Of The Scientific Approach In Integrative Thematic Learning To Support Communication Skills of Elementary School Teachers in Cluster IX Surakarta
}

\author{
Oktiana Handini, M Furqon Hidayatullah, Moch Ahkyar, Gunarhadi
}

\begin{abstract}
This study aims to determine the Communication Skills of Elementary School teachers through the implementation of the Scientific Approach in Integrative Thematic Learning. this research was conducted on cluster IX Surakarta as many as 10 teachers. The research method used is a qualitative research method with participant observation techniques, interviews and documentation. Participant observation place when Integrative Thematic Learning with the Scientific Approach was carried out by teachers. The validity of the data is done by triangulation techniques which include: triangulation of methods, data and sources. the results of the study indicate that the Scientific Approach provides opportunities for teachers to think critically and creatively in broadening their learning horizons. where as Integrative Thematic Learning helps teachers and students collaborate, express as, find problems, determine alternative problem solving and interact with each other. The implementation of Scientific Approach in Integrative Thematic Learning builds interpersonal communication and intrapersonal communication in everyday life, Communication Skills is a need to interact with each other through dialogue, listening, asking questions, delivering messages and talking politely with others. The conclusion of this study is that the implementation of the Scientific Approach provides opportunities for teachers and students to interact, talk effectively, communicate in Integrative Thematic Learning. the conclusion is the teacher Communication Skills are trained and formed effectively to improve Communication Skills through effective learning, varying models, strategies, methods, and techniques in a variety of ways.
\end{abstract}

keywords: Communication Skills, Scientific Approach, Integrative Thematic Learning

\section{INTRODUCTION}

Curriculum changes and the development of learning carried out by the government are currently aimed at developing educational curricula in Indonesia along with the progress of the age. Now in Indonesia, the curriculum applied is The 2013 curriculum by applying Integrative Thematic. The 2013 curriculum is an improvement of the 2006 curriculum, namely KTSP (Education Unit Level Curriculum). Integrative Thematic is a natural approach to the Scientific Approach. The implementation of the Scientific Approach in the Integrative Thematic Learning system is focused on the role of the teacher in the school learning process. It was stated in Law No. 20 of 2003

Revised Manuscript Received on April 19, 2019.

Oktiana Handini

M Furqon Hidayatullah

Moch Ahkyar

Gunarhadi
Chapter IV Article 7: (1) Parents have the right to participate in choosing educational units and obtaining information about the development of their children's education. (2) Parents of compulsory education children are obliged to provide basic education to their children. Thus the teacher has a big role in achieving learning appropriately and effectively in Integrative Thematic Learning.

The Scientific Approach is a learning process that is designed so students actively construct concepts, laws or principles through the stages of observing (to identify or find problems), formulate problems, submit or formulate hypotheses, collect data with various techniques, analyze data, draw conclusions and communicate concepts, laws or principles that are "discovered". Scientific Approach is intended to provide understanding to students in knowing, understanding various materials using a Scientific Approach, that information can come from anywhere, anytime, does not depend on the same direction information from the teacher. Therefore, the learning conditions that are expected to be created are directed at encouraging students to find out from various sources through observation, and not just being told.

At present education is based on efforts to achieve Basic Education for All. the condition of students who vary their level of knowledge and abilities. Students as a golden generation need quality basic education, namely basic education that is able to equip our generation of gold into luck. through quality basic education believed, Generasi Emas Year 2045 is able to realize the peak of its civilization The competencies and skills of the latest teachers are (1) Technological literacy, (2) Knowledge deepening, and (3) Knowledge creation (Zuhdan K Prasetyo 2019). consists of six components of the education system, namely policy, curriculum \& assessment, pedagogy, information technology and communication, organization \& administration, and teacher professional development. communication needs and interact with the environment, so that the teacher is required to have the ability communicate well. This communication ability is directed at educative communication which refers to increase in cognitive, affective and spikomotoric domains.

This research is based on the results of the first study Oktiana Handini (2016). The contribution of the 
Competence and Professional Competence Toward Class Management (Study in Elementary School at Banjarsari Subsdistric). data has shown that there are contributions to pedagogical competence and professional competence to class management. the variables chosen on the independent variables are pedagogic competence and professional competence can explain the variation in class management variables by $95.7 \%$, The second study Oktiana Handini (2018) The Teachers Readiness of Integrative Thematic Learning in Elementary School (Exploration Study at 2017/2018 Academic Year Elementary School Teacher of Surakarta). in fact, in Surakarta after Indonesia has published curriculum 2013, some teachers have not been ready yet. they have many problems such as teacher readiness in teaching models, teaching media, and teaching methods in scientific learning processes. The teachers readiness of Integrative Thematic Learning in Elementary School has been done in simple process.

Phenomenon, teachers are not communicative and cannot bring a pleasant learning atmosphere. Now days many teachers in Elementary School in carrying out learning are still classical and traditional, that is, as is usually done, it is still a daily routine. when showing that the learning activities of students are generally still limited to carrying out teacher instructions, students are lacking active, students do not have the courage to express self opinion spontaneously if not given the opportunity and teacher's question. so that the learning atmosphere in the classroom is not conducive and tends to be rigid. This situation is a problem for teachers in the learning process, so the teacher's role becomes very dominant in this problem. creative and innovative teachers in delivering learning information will build effective communication. research that was done in the title of "The Implementation of the Scientific Learning In Support of Communication Communication Skills of Elementary School Teachers in Cluster IX Surakarta”.

\section{LITERATURE}

\section{a. The Scientific Approach}

Scientific Approach is a learning process that is designed so that students actively construct concepts, laws or principles through the stages of observing (to identify or find problems), formulate problems, submit or formulate hypothesescollect data with various techniques, analyze data, draw conclusions and communicate concepts, laws or principles that are "discovered". Scientific Approach is intended to provide understanding to students in knowing, understanding various materials using a Scientific Approach, that information can come from anywhere, anytime, does not depend on the same direction information from the teacher. learning that is expected to encourage students to find out from various sources through observation, and not just being told. scientific modeling in classroom practices for high demand on teachers, modeling requires the development of competence and development of a different understanding of science and science as well as changes in their classroom practices. (Mirta Elisabeth Gonzales Maza, 2015.2).

The application of the Scientific Approach to learning involves process skills, the 2013 curriculum such as observing, classifying, measuring, predicting, explaining, and concluding. the Scientific Approach is very relevant to three learning theories, namely Bruner's theory, Piaget's theory, and Vygotsky's theory. Bruner's learning theory is also called discovery learning theory. There are four main things related to Bruner's learning theory (in Carin \& Sund, 1975). first, the individual only learns and develops his mind when he uses his mind. Second, by carrying out cognitive processes in the process of discovery, students will gain intellectual sensation and satisfaction which is an intrinsic appreciation. third, the only way for someone to learn the techniques of making discovery is that he has the opportunity to make discoveries. Fourth, by making a discovery it will strengthen memory. this Scientific Approach learners will learn exploratively through the steps of learning to observe, ask, process, try, present, conclude and create (Daryanto, 2013). observe: learning activities that can be carried out by students such as reading, listening, listening, seeing (with or without tools). Competencies that want to be developed through learning experiences OBSERVE. is training sincerity, accuracy, and the ability to find information. questioning: Learning activities that can be done is asking questions about what information is not understood from what is observed or questions to obtain additional information about what they are observing. the questions that students ask should be able to start from factual questions that lead to hypothetical questions (guesswork). the competencies developed are the development of creativity, curiosity (curiousity), the ability to formulate questions for the development of critical thinking skills, and the formation of lifelong learner characters. gather information: read various other sources of information other than those found in textbooks, observe objects, observe events, carry out certain activities, and interview with a resource person. competencies to be developed include: students will develop meticulous attitudes, be honest, polite, respect the opinions of others, have the ability to communicate, have the ability to gather information in various ways, develop learning habits, to become a personlifelong learners (life long learner).associate: The form of learning activities that can be provided by educators include information processing starting from a variety of information that deepens and extends information to information that is mutually supportive, even different or conflicting. through this learning experience it is expected that students will develop honest, thorough, disciplined, obedient rules, work hard, be able to apply a procedure in thinking deductively or inductively to draw a conclusion. communication: Providing a learning experience to conduct learning activities in the form of conveying the results of observations that have been made, conclusions obtained based on the results of the analysis, carried out either verbally, in writing, or in other ways and media. This is intended so that students have the opportunity to develop their competencies in developing honesty, thoroughness, tolerance, thinking systematically, expressing opinions in a short and clear manner, to being

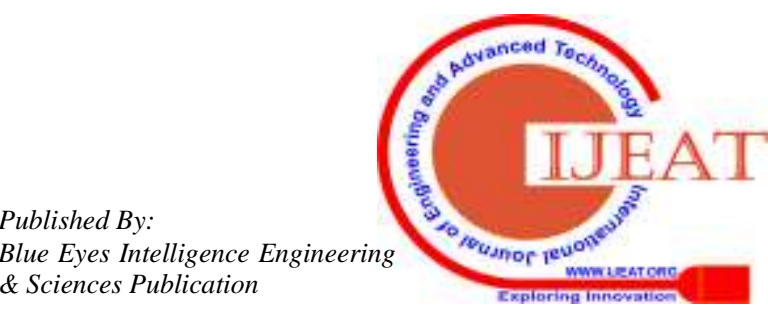


able to speak properly and correctly.

\section{b. Integrative Thematic Learning}

Integrative Thematic Learning is a learning approach that integrates various competencies from various subjects into various themes. integration is carried out in two ways, namely the integration of attitudes, skills and knowledge in the learning process and the integration of various related basic concepts. The theme of knitting the meaning of various basic concepts so that students do not learn the basic concepts partially. thus learning provides students with the full meaning as reflected in the various themes available. In Integrative Thematic Learning, the theme chosen relates to nature and human life. the concept of Integrative Thematic Learning models studied in Indonesia is an Integrative Thematic Learning concept developed by Fogarty (1991). The Integrative Thematic Learning applies to themes as the procedures of learning activities which integrate some subjects. the learning activities process provides a meaningful experience for learners in understanding the concepts. Learners: Learn how to learn from other concepts that they have learned (Putri Zudhah Ferryka, 2017). Integrative Thematic Learning is a learning pattern that integrates several subjects with specific themes. This themebased learning is more focused on achieving graduate competencies that are balanced between soft skills and hard skills that cover attitude, knowledge and skills. Integrative Thematic Learning does not separate subjects but material updates lead to the discussion of each theme.

\section{c. Communication Skills}

Communication is a social process between individuals and uses symbols to create and interpret the meaning of messages between communicators and communicants (Richard West and Lynn H. Turner 2012: 9). the message conveyed by the communicator in the form of information and news so that it can be understood by the communicant effectively. (Werner J Saverin: 2011 487). communicating is an activity that we always do every day, therefore Communication Skills are very necessary in communication so that the communication we do can run smoothly and there is no misinterpretation between communicators and communicants.

Communication Skills (Communication Skills) is a skill, ability or intelligence in communicating with others Communication Skills are the main skills that individuals should have who want to establish relationships between individuals, communities, groups, and organizations wherever they are. in the world of education Communication Skills are needed by teachers in the learning process of learning.

Effective Communication Skills are fundamental to success in learning processes. Teachers need high level Communication Skills because Communication Skills usually enjoy better interpersonal relationships with their students. Effective communication is a key interpersonal skill and learning how can you improve communication has many

benefits.

(https://www.skillsyouneed.com/ips/improving-

communication.html).

\section{METHODOLOGY MATERIALS}

\subsection{Population}

The population were 10 Elementary School teachers in the Ninth cluster and the sampling technique was total sampling. consists of Tempel Elementary School, Banyuanyar 2 Elementary School, Source 5 Elementary School, Alfalah Elementary School and Focus Elementary School.

\subsection{Research Method}

The research method used is descriptive qualitative research method with participant observation techniques, interviews and documentation. Participant observation took place when Integrative Thematic Learning with Scientific Approaches was carried out by the teacher. the validity of the data is done by triangulation techniques which include: triangulation of methods, data and sources. Participant observation is used to obtain data and information directly during the learning process, and interviews are used to obtain data on teachers and students. interviews with students focused on the level of readiness of students, setting assignments from teachers and enriching assignments from the teacher. Documentation is used to obtain teacher activity data, records of teacher portfolios and student learning outcomes that have been stored by the teacher. all data are collected and recorded in the research field data record. Data from three, namely participant observation techniques, interviews and documentation. Then the data is triangulated, so that it meets the data requirements (data validation).

\section{RESULT AND FINDINGS}

\subsection{Result}

The implementation of Integrative Thematic Learning in Elementary Schools according to the 2013 curriculum requires teachers to change their mindsets, paradigms, attitudes and teacher-centered learning patterns into learnercentered learning patterns. The activity of participants is to be the focus of learning. intuition is needed preparedness, the ability to manage learning and large responsibilities. The results of this study show that:

4.1.1. All Surakarta IX Primary School teachers have implemented the 2013 Curriculum with the Scientific Approach in the learning process.

4.1.2 .The teacher obtained an explanation of the understanding of the Scientific Approach and Integrative Thematic Learning which was coordinated by the Surakarta Education Office, and coordinated with cluster IX Surakarta through seminars, workshops and training on Teacher Activity Groups (KKG).

4.1.3 The results of the implementation in an integrated component of Curriculum 2013, the Scientific Approach and Integrative Thematic Learning and assessment shows that:

4.1.3.1 Understanding of 2013 Curriculum shows the results 
6 Elementary School teachers understanding well,

2 Elementary School teachers understanding medium

2 Elementary School teachers understanding low.

4.1.3.2 Understanding and Scientific Approach shows results :

4 Elementary School teachers have carried out the Scientific Approach steps correctly.

4 Elementary School teachers have not carried out the Scientific Approach steps correctly. This is due to learning facilities and learning media.

2 Elementary School teachers do not understand and have not been able to fully implement the Scientific Approach steps correctly. This is due to learning facilities barriers, learning media, training and learning opportunities.

4.1.3.3 Application of Integrative Thematic Learning in schools shows :

6 Elementary School teachers have observed, classified, measured, predicted, explained, and concluded according to content standards according to curriculum demands in the learning process in accordance with the 2013 Curriculum.

2 Elementary School teachers have implemented Integrative Thematic Learning well, according to the content criteria, and the learning process with the development of learning models and strategies in accordance with the 2013 curriculum.

2 Elementary School teachers have not consistently observed, classified, measured, predicted, explained, and concluded according to content standards according to curriculum demands in the learning process in accordance with the 2013 Curriculum.

Communication Skills of Elementary School teachers in the learning process are generally still done verbally directly, monotonously and lacking in variation. Primary school teacher Communication Skills have not used interactive social media assistance such as whatsApp, Short Messager System and e-mail. This is caused by the maximum facilities, the level of education and socioeconomic parents of heterogeneous students. Interpersonal communication between Elementary School teachers and students only occurs in schools, and interpersonal communication between Elementary School teachers and parents is not optimal because it only uses oral messages to students.

Various things that underlie the implementation of the 2013 curriculum in Elementary Schools are (a) students in the age of development are still at the level of thinking holistically, so that the formation of holistic learning competencies is also needed based on attitude, knowledge andskills. (b) Learners access information through sophisticated information technology. (c) Supporting students to have responsibility, care for the environment and high soft skills. high soft skills include Communication Skills intrepersonally and intrapersonal, critical thinking. All of them are aimed at developing creative, innovative students. the results of the study indicate that the Scientific Approach provides an opportunity for teachers to think critically and creatively in broadening their learning horizons. whereas Integrative Thematic Learning helps teachers and students collaborate, express ideas, find problems, determine alternative problem solving and interact with each other. the implementation of the Scientific Approach in Integrative Thematic Learning builds interpersonal communication and intrapersonal communication. in everyday life, Communication Skills (CS) is a need to interact with each other through dialogue, listening, asking questions, delivering messages and talking politely with others.

The results of the study showed 10 teachers, consist of 6 teachers managed to have good, effective Communication Skills and 2 teachers were able to communicate well while 2 teachers communicated less fluently.

\section{CONCLUSION AND SUGGESTION}

\subsection{Conclusions}

This study that the implementation of the 2013 Curriculum through Integrative Thematic Learning has been carried out by Elementary School teachers in cluster IX Surakarta, but the implementation of the Scientific Approach has not been carried out procedurally by all Integrative Thematic Learning steps. conditions that occur because Elementary School teachers in cluster IX Surakarta, effectively have oral Communication Skills and social interaction with their students. the implementation of the Scientific Approach provides opportunities for teachers and students to interact, speak effectively, communicate in Integrative Thematic Learning. So that Communication Skills (CS) are trained and formed that are good and effective.

\subsection{Suggestion}

The results of this study provide suggestions for teachers and students, in order to train and improve communication (CS) skills through effective learning, varied models, strategies, methods, and techniques. supported by training on social skills and teacher soft skills to significantly influence Integrative Thematic Learning.

\section{REFERENCES}

1. Colham Rose,Walcom J. Nichole (2015). Accelerated Learning for the 21 st Century Terjemahan Dedy Ahmad dkk, Bandung : Nirwana

2. Daryanto.(2014) Pendekatan Pembelajaran Saintifik Kurikulum 2013. Yogyakarta: Gava Media.

3. Forgotsky (1991), The Mindful School: How to Integrate The Curricula. Patine Illinois: IRI/Skylight Publishing Inc.

4. HM. Musfiqon dan Nurdyansyah,(2015) Pendekatan Pembelajaran Saintifik, Sidoarjo : Nizamia Learning Center .

5. Mirta Eliabeth Gonzalez Maza, 2014, Exploring Teachers' Learning : A Teacher's Experiences Integrating Scientific Modelling in The Science Classroom, Urbana,Illinois.

6. Oktiana Handini (2016) The contribution of Paedagogic Competence and Professional Competence Toward Class Management (Study in Elementary School at Banjarsari Subsdistric). Jurnal ISPI Jateng Volume 3 Nomor 1.

7. (2018) The Teachers Readiness Of Integrative Thematic 
8. Learning in Elementary School (Exploration Study at Elementary School Teacher of Surakarta Academic Year 2017/2018). Proceeding Conference on Technology, Education and Social ..., 2018 - ejurnal.unisri.ac.id

9. Putri Zudhah Ferryka, (2017) Analyzing the ThematicIntegrative Content, the Scientific Approach, and the Authentic Assessment in the Theme 1 Textbook for Grade II Students of Elementary Schools, Jurnal Prima Edukasia, 5 (2), 2017, 172-185

10. Richard West dan Lynn H.Turner (2012) Introducing Communication Theory : Analysis and Application, NY : Addition Wesley Longman Inc.

11. Werner J Saverin (2011) Communication Theory, NY : Mc.GrawHill.(https://www.skillsyouneed.com/ips/impro ving-communication.html). 